\title{
A CONCEPÇÃO DE VALOR-TRABALHO EM MARX
}

\section{$\underline{\text { Jordania Barbosa Araújoí; Adriana Santos Tabosa }}{ }^{2}$;}

1. Bolsista PROBIC/UEFS, Graduanda em Filosofia, Universidade Estadual de Feira de Santana, e-mail: jordania_b.araujo@hotmail.com

2. Orientadora, Departamento de Ciências Humanas e Filosofia, Universidade Estadual de Feira de Santana, e-mail: adriana_tabosa@yahoo.com.br

PALAVRAS-CHAVE: valor-trabalho; capital; ser social.

\section{INTRODUÇÃO}

O problema na determinação de um padrão de comensurabilidade do valor nas relações econômicas e sociais ganha destaque e relevo no seio de importantes teorias de grandes autores, seja sob o prisma essencialmente econômico seja pelo crivo filosófico, uma vez que os cálculos matemáticos não conseguem isoladamente transcrever as relações humanas, deste modo, torna-se evidente a necessidade de realizar uma investigação acerca das contribuições econômicas bem como filosóficas da teoria do valor-trabalho em Marx.

A investigação se propõe a percorrer os fundamentos que giram em torno da concepção valor-trabalho no âmbito filosófico. Deste modo, será necessário retomar as obras de Marx, especialmente $O$ Capital, evidenciando e examinando suas principais reflexões e contribuições para a temática.

Neste sentido, será imprescindível adentrar no sistema de conceitos que Marx delineia para a sua teoria do valor, ressaltando o que subjazem a todas as acepções em uma rede própria de fundamentos, para que se possa tornar cristalina o papel da existência humana no interior da teoria do valor, na qual irá perpassar o ponto fulcral das teorias econômicas que é justamente a expressão das relações que se fundam em um contexto social no processo produtivo.

\section{MATERIAL E MÉTODOS OU METODOLOGIA (ou equivalente)}

A metodologia da pesquisa filosófica consiste na leitura, na análise crítica e reflexiva de textos. A metodologia da pesquisa constituiu-se de três etapas: I) pesquisa da referência bibliográfica pertinente à temática; II) leitura e análise sistemáticas dos textos; III) ênfase no trabalho reflexivo que possibilite a identificação do conceito central que norteia a investigação. 
Foi estabelecida a análise da fonte primária, no que se refere ao arcabouço conceitual que gira em torno do tema da pesquisa. Neste sentido foram abordados pontos principais da obra O' Capital, os quais se vincularam com a investigação do desenvolvimento da conceituação valor-trabalho.

\section{RESULTADOS E/OU DISCUSSÃO (ou Análise e discussão dos resultados)}

É imprescindível compreender a função primordial e inicial do trabalho em criar valor de uso, na qual fundamenta as possibilidades de realização social da produção, uma vez que é a partir da viabilidade em suprir as diversas necessidades da vida humana que o trabalho se efetiva enquanto produtor de valor de uso e, por conseguinte estabelece as vias para a concretização das formas de sociabilidade do processo produtivo, inclusive na configuração capitalista.

Para adentrar nos meandros da teoria do valor em Marx, é necessário destacar a mercadoria e seu duplo aspecto que se desdobra nas concepções do seu valor de uso e valor de troca. O valor de uso se produz através da efetivação do trabalho concreto, posto que este último se configura no campo técnico material, possibilitando a concretização do sustentáculo da vida humana por meio do processo produtivo individual, emerge desse processo a expressão do trabalho concreto, uma vez que a fundamentação de seu trabalho se dá na esfera privada, na qual poderá se transfigurar para o formato social quando a equiparação dos produtos de diferentes produtores seja realizada.

O valor de uso é constituído pela utilidade, na qual não pode ser mensurada por intermédio do trabalho, todavia, o valor de uso expresso em dado produto, que se origina do trabalho humano e dispõe de efetiva utilidade, não se manifesta enquanto mercadoria, já que o direcionamento para a sua produção foi feito em vista da satisfação da necessidade própria, o que caracteriza primordialmente o valor de uso.

Desta maneira, neutralizando os valores de uso das mercadorias no interior das relações de troca, torna-se eminente apenas uma característica do produto, a saber, de ser fruto da produção do trabalho (MARX, 1985). Quando ocorre a supressão da funcionalidade de determinada mercadoria, anula-se concomitantemente a expressão de utilidade no trabalho empreendido para sua realização, sendo assim, transcorre o rompimento das diversas formas concretas de trabalho, o que permite a totalização destes trabalhos, possibilitando a anulação das diferenças que culminam na conceituação efetiva de trabalho humano abstrato. 
Segundo Marx, decorre da objetivação do trabalho humano indiferenciado em dada produção o dispêndio da força de trabalho. Este caráter primordial que configura o processo produtivo resulta na solidificação geral que expressa o trabalho humano. Portanto, o valor é o que há de comum, desvelado na relação de troca ou valor de troca da mercadoria. Neste sentido, o trabalho humano abstrato ganha relevo significativo, já que a sua materialização permite a exibição do valor.

Todavia, o valor investigado tão somente em suas características concretas se manifesta de forma imperceptível, uma vez que o que configura o valor enquanto tal é resultante do interior das relações sociais, cuja verificação se dará por intermédio das relações de troca, já que a objetividade de dada mercadoria se consolidará enquanto valor quando sua expressão manifestar a unidade social do trabalho.

\section{CONSIDERAÇÕES FINAIS (ou Conclusão)}

Sendo assim, o processo de produção inicia-se através da ação humana e finaliza-se na efetivação do produto, o qual é engendrado o objetivo preexistente que é idealizado e empreendido no decorrer de todo o processo produtivo. Neste sentido, a finalidade primordial da efetivação do produto não compreende unicamente a produção de coisas dotadas de utilidade, todavia, o ponto fulcral para a consolidação do produto se expressa no caráter de transação econômica, ou seja, a produção de determinado objeto é elaborada em vista da sua viabilidade de troca. Desta maneira, na medida em que o processo produtivo capitalista cria valores de uso com o objetivo exclusivo de exibir e viabilizar o valor de troca submete assim a mercadoria à venda, com a finalidade de produzir além de valor de uso, valor.

\section{REFERÊNCIAS}

BELLUZZO, Luiz Gonzaga de Mello. Valor e Capitalismo. São Paulo, Brasiliense, 1980.

GIANNOTTI, José Arthur. Trabalho e Reflexão. São Paulo: Editora Brasiliense, 1983. MARX, K. O Capital: crítica da economia política. Tradução por Regis Barbosa e Flávio R. Kothe. São Paulo: Abril Cultural, 1985a. Livro 1, v.1, t.1. (Os economistas). MARX, K. O Capital: crítica da economia política. Tradução por Regis Barbosa e Flávio R. Kothe. São Paulo: Abril Cultural, 1985c. Livro 1, v. 1, t. 2 (Os economistas). 
MARX, K. Manuscritos econômico-filosóficos e outros textos escolhidos. São Paulo: Abril Cultural, 1974. (Os Pensadores).

MARX, K. Contribuição a Critica da Economia Política. Tradução Maria Helena Barreiro Alves. São Paulo: Martins Fonte, 2016.

RUBIN, Isaac Illich. A Teoria Marxista do Valor. São Paulo, Brasiliense, 1980.

SINGER, Paul. "Trabalho Produtivo e Excedente". In Revista de Economia Política, vol. 1, nº 1. São Paulo, Brasiliense, 1981.

TABOSA, Adriana Santos. O problema da análise econômica em Aristóteles: um estudo sobre a distinção dos conceitos de economia e crematística. Campinas, SP: [s. n.], 2007 